\title{
The Influence of Sufficiency Economy Philosophy Practice on SMEs' Performance in Thailand
}

\author{
Muttanachai Suttipun, Afsa Arwae
}

\begin{abstract}
A B S T R A C T
Objective: The objective of the article is to investigate the extent and level of sufficiency economy philosophy (SEP) practice, the performance measured by the balanced scorecard (BSC) of small and medium-sized enterprises (SMEs) in Thailand, and to test the influence of SEP practice on SMEs' performance measured by BSC.

Research Design \& Methods: Using stratified sampling, 600 SMEs were adopted as the sample in this study. Self-reported data was collected using a mailed questionnaire containing items incorporating a five-point Likert scale. The data was initially analysed by descriptive analysis, correlation matrix, and multiple regression.

Findings: The study found that both SEP practice and performance measured by the BSC of SMEs were at a high level. Moreover, the moderation element was the most common SEP practice followed by the morality condition, the reasonableness element, the self-immunity element, and the knowledge condition. The multiple regression analysis indicated that all the elements and conditions of SEP positively and significantly influenced performance measured by the BSC. Using control variables, the study also found the significant relationship between firm size, firm age, and SMEs' performance.

Implications \& Recommendations: Business owners and top management can use SEP as a practical management tool with which to operate their business instead of adopting Western management models.
\end{abstract}

Contribution \& Value Added: The study findings can demonstrate that stakeholder theory can be used to explain SMEs in Thailand putting SEP into practice in order to satisfy stakeholder demands for better performance.

\begin{tabular}{|c|c|}
\hline Article type: & research article \\
\hline Keywords: & $\begin{array}{l}\text { sufficiency economy philosophy; performance; balanced scorecard; } \\
\text { small and medium enterprises; Thailand }\end{array}$ \\
\hline JEL codes: & M10, M40, M41, N15, D41, D43, E58, G18, G21 \\
\hline Received: 23 [ & ember $2019 \quad$ Revised: 9 May $2020 \quad$ Accepted: 8 June 2020 \\
\hline
\end{tabular}

\section{Suggested citation:}

Suttipun, M., \& Arwae, A. (2020). The Influence of Sufficiency Economy Philosophy Practice on SMEs' Performance in Thailand. Entrepreneurial Business and Economics Review, 8(2), 179-198. https://doi.org/10.15678/EBER.2020.080210 


\section{INTRODUCTION}

One of the major causes of the Asian financial crisis in 1997, dubbed the Tom Yum Goong crisis was that most enterprises had adopted Western management methods in their businesses (the Anglo-American approach; Kantabutra, 2006; Mongsawad \& Thongpakde, 2016), which leads to enterprises prioritising short-term performance by focusing only on certain groups of stakeholders, such as creditors, shareholders, and investors, rather than concentrating on long-term performance and the social and environmental impacts of their operations (Avery, 2005). Thailand was the first country affected by the crisis, which caused many economic problems. For example, a large number of enterprises went bankrupt, and a large number of workers were laid off. Thus, the Thai government derived insufficient revenue from corporate or personal income taxation. However, as a means of solving that crisis, the sufficiency economy philosophy (SEP) was adopted as a business model in Thailand. SEP focuses on long-term rather than short-term performance, balancing the economic, social, and environmental perspectives, and meeting the demands of all stakeholder groups (Suttipun, 2019). SEP, its concepts, and practice were created and developed by His Majesty the King of Thailand, Bhumibhol Adulyadej. SEP encompasses three elements: moderation, reasonableness, and self-immunity; along with two conditions of knowledge and morality. The main aim of the SEP in regard to business enterprises is to achieve sustainable development through what Thai Buddhists call the Middle Path (Mongsawad, 2010; Jitsuchon, 2019).

To put SEP into practice, business enterprises have to focus on long-term rather than short-term performance, but also on emphasising the maximisation of wealth rather than profit (Kantabutra, 2010). Furthermore, performance under SEP is based on the notion that one should attend to the demands of all stakeholders. The advantage of applying SEP in practice is that it leads enterprises to better financial and non-financial performance. The most common performance measurement tool by which both financial and non-financial performance can be measured is the balanced scorecard (BSC), developed by Kaplan and Norton (1992), which aims to evaluate business performance based on both its financial and non-financial aspects, taking into account strategic planning and management (Kaplan \& Norton, 1996) and the notion of sustainable development. The BSC is divided into five perspectives: financial, customer, internal process, learning, and environmental. Thus, the BSC is concerned with the social and environmental impacts of the actions and activities of business enterprises (Garrison et al., 2015).

However, although a number of previous studies examines the influence of SEP practice and disclosure on financial performance (Suriyankietkaew \& Avery, 2016; Suttipun \& Saefu, 2017; Suttipun, 2019), firm value (Kantabutra, 2006; 2010), and market price (Nuttavuthisit, 2005; Pruetipibultham, 2010), no published study investigates the influence of SEP practice on both financial and non-financial performance measured by the BSC. Therefore, there is currently no understanding of the direction of the relationship between SEP practice and performance as measured by the BSC. This may be because even though most prior studies find that SEP practice and disclosure positively influences financial performance (Pruetipibultham, 2010; Suriyankietkaew \& Avery, 2016; Suttipun \& Saefu, 2017; Suttipun, 2018), putting SEP into practice may entail higher costs for business 
enterprises, which may result in their producing lower financial and non-financial performance. Moreover, previous studies of SEP practice and disclosure focus on large-scale enterprises in capital market (Kantabutra, 2006; 2010; Suttipun \& Saefu, 2017; Suttipun, 2019), but there is limited research available that would focus on small and medium-sized enterprises (SMEs; Suriyankietkaew \& Avery, 2016).

SMEs are considered to be one of the main drivers of the new-world economy with important implications for job creation and employment, new product and service generation, research and technology development, tax revenue collection, and business responsibility (Williams et al., 2018). Based on data from the OECD (2018), SMEs in developing countries around the world account for over $45 \%$ of total employment and over $33 \%$ of gross domestic product (GDP). However, the SME sector has suffered a high rate of bankruptcies of over 69\% since 2002 (Veskaisri et al., 2007), the main reasons for this being that SMEs lack clearly defined strategies and appropriate management tools, conduct insufficient research and development, and are insufficiently capitalised (Kulkalyuenyong, 2018). In Thailand, although SMEs account for over $40 \%$ of national GDP, $80 \%$ of total employment, and $99 \%$ of the total number of Thai enterprises (OSMEP, 2018), they still have limitations compared to large-scale enterprises and suffer a higher rate of failure (Kulkalyuenyong, 2018).

Based on the problems outlined above, the current study has two main objectives expressed as research questions:

1. What are the extent and level of SEP practice and corporate performance of SMES in Thailand?

2. Does the practice of SEP by SMEs influence performance as measured by the BSC?

The study used an appropriate methodology adapted from prior related literature. Using stratified sampling, 600 SMEs from four main regions of Thailand (northern, north-eastern, central, and southern Thailand) were adopted as the sample in this study. A mailed questionnaire collected data in three sections as general information about SMEs, the SEP practice of SMEs, and the SMEs' performance according to the balanced scorecard (BSC), on a five-point Likert scale. The data was initially analysed by descriptive analysis, correlation matrix, and multiple regression. Sensitivity analysis was also used to confirm the finding.

The study can be expected to provide several contributions; in terms of its theoretical contribution, the study can demonstrate that the stakeholder theory is capable of explaining the advantages of businesses putting SEP into practice to satisfy their stakeholders' demands. The study will also shed light on SMEs using Eastern management practices in an emerging economic nation, with the benefits assessed with a Western performance measurement tool: the BSC. In terms of its practical contribution, by demonstrating the positive influence of putting SEP into practice on both financial and non-financial performance measured by the BSC, businesses will be encouraged to pursue the goal of sustainable development.

The following section will review the literature relevant to the theoretical background of the study, the SEP, its concept and practice, and performance measurement with the BSC, and will be concluded with hypotheses development. Next, the population, sampling method, and composition of the sample will be described, followed by the elaboration of data collection and analysis. The findings are then presented and discussed, and the paper concludes with a summary and suggestions for further research. 


\section{LITERATURE REVIEW}

The review of previous literature relevant to this study is divided into three sub-sections: theoretical perspective, corporate performance as measured by the BSC, and the SEP practice, including hypothesis development.

\section{Theoretical Perspective}

Although different theoretical approaches have been used to explain the management strategies used by businesses - such as agency theory, institutional theory, legitimacy theory, and stakeholder theory - the theoretical perspective most often adopted to explain the motivation for businesses to employ SEP is stakeholder theory. This is because stakeholder theory is concerned with the ways that businesses manage their stakeholders (Freeman, 1984; Kantabutra, 2006; Suttipun \& Saefu, 2017; Suttipun, 2018). Therefore, the current study used stakeholder theory to explain the extent and level of SEP practice and corporate performance of SMEs in Thailand, measured by the BSC and the influence of SEP practice on corporate performance as measured by the BSC.

Stakeholder theory is concerned with the relationship of a business's owners and its senior management with its diverse stakeholders and their responsibility towards those stakeholders (Freeman, 1984; Cheng \& Fan, 2010). A good relationship can result in a positive reputation, higher firm value, competitive advantage, and better performance. The main reason is that all stakeholders have something at risk in a business as well as having the power to affect that business, its actions, activities, decisions, policies, or even management practices (Collier, 2008; Parmar et al., 2010). Business's stakeholders may include not only shareholders, creditors, and investors, but also customers, workers, suppliers, competitors, regulators, the media, the local community, and even future generations (Carrol \& Bucholtz, 2006). Therefore, all businesses need to satisfy the demands of numerous stakeholder groups and the interaction with each stakeholder group needs to be managed )Gray et al., 1998(. Stakeholders are defined as those who can influence or be influenced by the achievement of business policies, goals, and decisions (Donaldson \& Preston, 1995). Each stakeholder group has a right to receive information from the business in which it is interested, even though stakeholders may not use that information, nor have a direct influence on the business )Deegan, 2002; Parmar et al., 2010(. Different groups of stakeholders have different degrees of power to compel and influence business actions and activities and different interests in business practices, and a business will tend to satisfy the demands of those stakeholders that are most important to its ongoing survival )Donaldson \& Preston, 1995; Joshi \& Gao, 2009(. Therefore, we conducted this study under the assumption that SEP is put into practice by SMEs in order to satisfy stakeholders and maintain good relationships with them )Suttipun, 2018(.

The notion of SEP practice in Thailand is accommodated by corporate stakeholder theory )Kantabutra, 2006; Suttipun \& Saefu, 2017; Suttipun, 2018( because Thai businesses focus not only on the demands of certain stakeholder groups, such as investors, shareholders, and creditors, but they also need to attend to and satisfy the demands of other stakeholder groups, such as customers, employees, suppliers, competitors, society and communities, and environmental lobbies )Suttipun, 2019(. Moreover, Thai businesses, which put SEP into practice and follow its concepts, are better able to meet 
stakeholders' demands and SEP also provides corporations with immunity from the results of uncontrollable events and the resilience to cope with new economic challenges Suttipun, 2018(.

\section{Performance Measured by the Balanced Scorecard}

In the past, business performance was exclusively measured by financial performance because it can be easily expressed in monetary units, and the results can be compared with competitors in the same industry. However, there are several limitations of reporting only financial performance including that: (1) it does not account for competitive advantage, (2) it does not focus on long-term performance, (3) it cannot be used for business forecasting, and (4) it does not encourage sustainable business development (Suttipun \& Sittidate, 2016). Therefore, non-financial performance has become a more common means of measuring corporate performance, but it is hard to express because it does not use monetary units (Norreklit, 2000). Moreover, it is hard to compare a company's non-financial performance with that of other enterprises because there are many different ways of gauging non-financial performance.

There are a number of performance measurement tools currently used to accommodate the reporting of non-financial performance, such as triple bottom line reporting and the BSC. This study used the BSC as its performance measurement tool because it is a more commonly used measurement tool in Thailand than triple bottom line reporting (Norreklit, 2000). The BSC was introduced by Kaplan and Norton (1992) as a means of measuring both financial and non-financial performance, which can support enterprises' strategic planning and management (Kaplan \& Norton, 1996). Within the BSC - as originally envisaged - there were four perspectives: financial, customer, internal process, and learning (Kaplan \& Norton, 1992). However, to accommodate the concept of sustainable development, Garrison et al. (2015) extended the model to incorporate environmental perspective into the BSC. Thus, the present study used the five perspectives of BSC to assess the reporting of corporate performance: financial, customer, internal process, learning, and environmental.

\section{Sufficiency Economy Philosophy Practice}

As noted in the introduction, SEP was adopted in Thailand as a means of recovering from the 1997 Tom Yum Goong crisis, which led to a large number of bankruptcies in Thailand, consequent upon companies prioritising short-term profitability at the expense of long-term performance (Mongsawad \& Thongpakde, 2016). A brainchild of His Majesty the King of Thailand, Bhumibhol Adulyadej, SEP was first conceptualised four decades ago. It is a philosophy that stresses the Buddhist middle path as the overriding principle for appropriate conduct by the populace at all levels )Mongsawad, 2010(. The philosophy encompasses three principles, moderation, reasonableness and self-immunity, which are governed by two conditions, knowledge and morality. Kantabutra 2010 ( elaborated on those three principals and two conditions. For example, the moderation principle revolves around the idea of corporate survival via the middle path, without resorting to extreme behaviour. Within the principle of reasonableness, firms act reasonably if their actions are based on accumulated experience, self-awareness, foresight, empathy and compassion. Furthermore, within the principle of self-immunity, enterprises are protected against unpredictable and uncontrollable factors. The 
condition of knowledge enables businesses to better understand the demands and expectations of their stakeholders, and morality refers to corporate responsibility, honesty, integrity, and trustworthiness, a characteristic crucial to long-term corporate sustainability (Jitsuchon, 2019).

Even though the SEP concept and practice is totally different to the traditional Anglo Saxon/US management approach which mainly focuses on (1) short-term performance rather than long-term performance, (2) some groups of stakeholder rather than all stakeholder groups, and (3) economic perspective rather than social and environmental impact (Mongsawad \& Thongpakde, 2016), there is a similar idea in terms of outcome and goal between the SEP concept and the modern Anglo Saxon management concepts such as the triple bottom line concept (Elkington, 1997; Skouloudis, 2009) and the Rhineland capitalism theory (Avery, 2005). This is because their concept and theory also focused on sustainable development (Jitsuchon, 2019) so as to balance not only economic perspective but also social and environmental perspectives. Moreover, the concept and theory still pay attention to all stakeholders' demands as part of the broad society (Donaldson \& Preston, 1995; Parmar et al., 2010).

In more detail, the components of SEP are used and mentioned in the East within three elements and two conditions: the SEP practice is quite similar to business operational practice from the West, such as corporate social responsibility, triple bottom line, and corporate governance (Suttipun, 2019). For example, the reasonableness element of SEP practice is similar to the strategic plan element of the triple bottom line practice (Skoudis, 2009; Jitsuchon, 2019), while the self-immunity element is also similar to the risk management in corporate governance (Suttipun, 2018). Moreover, the moderation element and the knowledge and morality conditions of SEP practice are quite similar to the operational fairness of corporate social responsibility (Parmar et al., 2010; Suttipun \& Sittidat, 2016). Finally, both SEP practice in the East and corporate social responsibility, triple bottom line, and corporate governance from the West focus on long-term outcome and sustainable development (Elkington, 1997; Carrol \& Bucholtz, 2006; Mongsawad \& Thongpakde, 2016).

In 2006, the United Nations (UN) formally recognised the importance of SEP as a path to sustainable development (UNESCO, 2013), and the UN has also continued to advocate the implementation of SEP programs and practice in many countries around the world. Therefore, SEP is currently implemented not only in Thailand but also in other countries, particularly where Buddhism influences national culture and society, namely Bhutan, Nepal, Laos, and Timor-Leste (Noim Uddin et al., 2006; Shone, 2014). For example, Bhutan's national philosophy has been developed from SEP (Noim Uddin et al., 2006) and is focused on gross national happiness - which has many more dimensions than GDP - and calls for a multidimensional approach to sustainable development consisting of maintaining harmony, increasing happiness, and balancing economic, social, and environmental impacts. In Laos, an SEP approach has been adopted as the guideline for a national program of sustainable, stable, and balanced development (Shone, 2014) and the SEP approach in Laos also provides a rationale for decision makers (i.e., the government and senior management) looking to improve the country's development model.

As noted above, the adoption of SEP requires corporations to focus on long-term rather than short-term performance )Kantabutra, 2010( and emphasises long-term wealth creation 
rather than myopic profit maximisation. Furthermore, corporate performance under SEP is based on the notion that the needs of all stakeholders are attended to, i.e. the needs of shareholders, investors, creditors, customers, employees, suppliers, competitors, society, communities and the environment. Thus, the demands of all stakeholders - not just those of the owners of financial resources - would be met by businesses practicing SEP. The philosophy also provides organisations with immunity from the results of uncontrollable events and the resilience to cope with new economic challenges.

Therefore, even though there has been no previous research reported about how putting SEP into practice influences performance measured by the BSC among SMEs in Thailand, some prior studies are relevant to the issues addressed in the present study. A number of previous studies finds a positive relationship between SEP practice and disclosure and financial performance (Pruetipibultham, 2010; Suriyankietkaew \& Avery, 2016; Suttipun \& Saefu, 2017; Suttipun, 2018). For example, Suttipun and Saefu (2017) and Suttipun (2018) both find that SEP disclosure has a positive relationship with financial performance as measured by the return on assets (ROA) of companies listed in the Stock Exchange of Thailand. Moreover, Suriyankietkaew and Avery (2016) reveal that there is a positive relationship between the sustainable development practice of Thai SMEs and their financial performance. As noted above, a positive relationship between SEP practice and firm performance can be explained by stakeholder theory because if businesses can satisfy all stakeholder demands, they derive benefits, such as an improved reputation, higher firm value, competitive advantage, and better financial performance (Cheng \& Fan, 2010; Jitsuchon, 2019).

However, there are some reasons why SEP practice may have a negative or neutral effect on the performance of SMEs in Thailand. Firstly, putting SEP into practice may entail increased costs because it would involve an SME's management changing their strategies from those typical of Western business concepts to those more typical of Eastern philosophies. This may entail SMEs accepting lower levels of performance, particularly when measured in financial terms. Secondly, SEP is not a Western business philosophy, which generally focuses on maximising profit. Instead, SEP focuses on sustainable development and encourages firms to balance their economic, social, and environmental performance. On the other hand, the BSC is a primarily Western performance measurement model, which was not designed to evaluate Eastern management strategies, such as the SEP practice. Therefore, there may not be a relationship between SEP practice and performance measured by the BSC. Finally, although a number of studies investigated the influence of SEP practice and disclosure on financial performance, no previous studies reported a relationship between SEP practice and non-financial performance.

Therefore, so as to answer the research questions, the study tested five hypotheses relating to the five elements and conditions of SEP, the moderation, reasonableness, and self-immunity elements, and the knowledge and morality conditions. We present the hypotheses below:

H1: The SEP moderation element has a positive influence on performance of SMEs in Thailand as measured by the BSC.

H2: The SEP reasonableness element has a positive influence on the performance of SMEs in Thailand as measured by the BSC.

H3: The SEP self-immunity element has a positive influence on the performance of SMEs in Thailand as measured by the BSC. 
H4: The SEP knowledge condition has a positive influence on the performance of SMEs in Thailand as measured by the BSC.

H5: The SEP morality condition has a positive influence on the performance of SMES in Thailand as measured by the BSC.

\section{MATERIAL AND METHODS}

The population of this study was all SMEs located in Thailand (Revenue Department, 2018). SMEs in Thailand are defined by the Ministry of Industry (2019) as an enterprise that has either less than 200 employees or total assets of up to 200 million baht. There are two types of SMEs in Thailand which are small and medium-sized enterprises. On the one hand, a small enterprise is an enterprise with less than 50 people employed or with total assets of up to 50 million baht. On the other hand, a medium-sized enterprise is an enterprise that has from 50 to 200 employees or total assets of no less than 50 million baht and up to 200 million baht. However, definitions and types of SMEs differ between Thailand and other countries. While Thailand has the above types of SMEs, European countries divided their SMEs into three types, which consist of micro, small, and medium-sized enterprises (European Commission, 2019). SMEs in European countries are identified as enterprises that have less 250 employees. Moreover, SMEs should also have a turnover of up to 50 million EUR or total assets of no more than 43 million EUR (Williams et al., 2018). We used two steps in selecting the sample for this study: quota and simple random sampling. In the first step, the study set a quota of 600 SMEs in Thailand within four regions of Thailand (northern, north-eastern, central, and southern Thailand) with 150 SMEs from each region. In the second step, simple random sampling was used to select 150 SMEs in each of the four regions mentioned above. Therefore, the sample used in this study consisted of 600 SMEs.

A mailed questionnaire modified from prior related studies was used to collect data from the sample of SMEs, relating to the extent and level of SEP practice and corporate performance, as measured by the BSC (Suriyankietkaew \& Avery, 2016; Williams et al., 2018). The SEP practice within three elements and two conditions was operationalised and adopted from prior related studies from Suttipun (2018 and 2019) who investigated the extent and level of SEP reporting of listed companies (large firms) in Thailand. The questionnaire was divided into three parts: (1) general information regarding the respondent SME, (2) the SME's SEP practice, and (3) the SME's performance as measured by the BSC (Appendix). The independent variables used in this study were the five elements and conditions of SEP consisting of the moderation, reasonableness, and self-immunity elements and the knowledge and morality conditions (Suriyankietkaew \& Avery, 2016; Suttipun, 2018), with performance as measured by the BSC as the dependent variable, which was further sub-divided into the five BSC perspectives, such as financial, customer, internal process, learning, and environmental (Hetthong, 2017; Plaisuan, 2015; Williams et al., 2018). In terms of control variables, SMEs' characteristics consisting of firm size, firm type, and firm age were used in this study by adopting from prior related studies (Suriyankietkaew \& Avery, 2016; Suttipun \& Saefu, 2017). In firm size, there were two types of SMEs in Thailand - small and medium-sized enterprises - while firm type was divided by the personal type of SMEs: ordinary person and juristic person. On the one hand, an ordinary person includes sole proprietorship, group of persons, and ordinary partnership. On the 
other hand, a juristic person includes limited partnership, a limited company, and a listed company (The Ministry of Industry, 2019). Finally, firm age was distinguished into two periods of less than 10 years and equal or more than 10 years. All the variables were measured by items in the questionnaire to which the participating SMEs responded on a fivepoint Likert scale ( 5 = the highest level, $4=$ high level, $3=$ moderate level, $2=$ low level, and 1 = the lowest level), as summarised in Table 1.

Table 1. Variable measurement of Thai SMEs in 2019

\begin{tabular}{|c|c|c|}
\hline Independent Variables & Notation & Measurement \\
\hline Moderation element & MODER & Five-point Likert scale \\
\hline Reasonableness element & REASO & Five-point Likert scale \\
\hline Self-immunity element & SELF & Five-point Likert scale \\
\hline Knowledge condition & KNOW & Five-point Likert scale \\
\hline Morality condition & MORAL & Five-point Likert scale \\
\hline Dependent Variable & Notation & Measurement \\
\hline SMEs' performance & BSC & Five-point Likert scale \\
\hline Control Variables & Notation & Measurement \\
\hline Firm size & SIZE & Dummy variable that $1=$ medium firm, and $0=$ small firm \\
\hline Firm type & TYPE & $\begin{array}{c}\text { Dummy variable that } 1=\text { ordinary person, and } 0=\text { juristic } \\
\text { person }\end{array}$ \\
\hline Firm age & AGE & $\begin{array}{c}\text { Dummy variable that } 1=\text { less than } 10 \text { years, and } 0=\text { more } \\
\text { than } 10 \text { years }\end{array}$ \\
\hline
\end{tabular}

Note: 5 = the highest level, $4=$ high level, $3=$ moderate level, $2=$ low level, and $1=$ the lowest level.

Source: adapted from Suttipun, 2018; 2019; Williams et al., 2018; Suriyankietkaew and Avery, 2016.

The interpretation of the responses to the second and third parts of the mailed questionnaire was based on the mean score of responses to the Likert-scale items interpreted on the rating scale shown below (Srisa-ard, 2010).

The average score of 1.00-1.50 defined as at the lowest level.

The average score of 1.51-2.50 defined as at a low level.

The average score of 2.51-3.50 defined as at a moderate level.

The average score of 3.51-4.50 defined as at a high level.

The average score of 4.51-5.00 defined as at the highest level.

The draft questionnaire was sent to five experts to review its reliability and to ensure that it fully covers all aspects of this study. The questionnaire was then revised based on the experts' suggestions and was then once again reviewed by the experts before being finalised and sent to the sample of SMEs. The questionnaire was tested to establish the Cronbach (1951) coefficient alpha that resulted in 0.880 , which means that - as it is higher than 0.60 - it indicates the satisfactory reliability of the questionnaire. Moreover, we show the validity and reliability test results in Table 2 below.

The data derived from the questionnaire was firstly analysed by averaging the responses to each item across the 600 SMEs constituting the sample in order to assess the extent of their SEP practice and the level of performance as measured by the BSC. Next, correlation matrix was used to test for multicollinearity between the variables and, finally, multiple regression to test for the influence of SEP practice on performance as measured by the BSC. We used the following regression equation: 


$$
\begin{aligned}
\mathrm{BSC}= & \beta 0+\beta 1 \cdot \mathrm{MODER}+\beta 2 \cdot \mathrm{REASO}+\beta 3 \cdot \mathrm{SELF}+\beta 4 \cdot \mathrm{KNOW}+ \\
& +\beta 5 \cdot \mathrm{MORAL}+\varepsilon \\
\mathrm{BSC}= & \beta 0+\beta 1 \cdot \mathrm{MODER}+\beta 2 \cdot \mathrm{REASO}+\beta 3 \cdot \mathrm{SELF}+\beta 4 \cdot \mathrm{KNOW}+ \\
& +\beta 5 \cdot \mathrm{MORAL}+\beta 6 \cdot \mathrm{SIZE}+\beta 7 \cdot \mathrm{TYPE}+\beta 8 \cdot \mathrm{AGE}+\varepsilon
\end{aligned}
$$

\begin{tabular}{|c|c|c|c|c|c|}
\hline \multirow{2}{*}{ No. } & \multirow{2}{*}{ Variables } & \multirow{2}{*}{ Item } & \multicolumn{2}{|c|}{ Pearson Correlation-validity } & \multirow{2}{*}{ Reliability } \\
\hline & & & Pearson (sig.) & Validity & \\
\hline \multirow{4}{*}{1.} & \multirow{4}{*}{ Moderation element } & MODER-A & $0.927^{* *}$ & Valid & \multirow{4}{*}{0.887} \\
\hline & & MODER-B & $0.880 * *$ & Valid & \\
\hline & & MODER-C & $0.909 * *$ & Valid & \\
\hline & & MODER-D & $0.895 * *$ & Valid & \\
\hline \multirow{4}{*}{2.} & \multirow{4}{*}{ Reasonableness element } & REASO-A & $0.921 * *$ & Valid & \multirow{4}{*}{0.883} \\
\hline & & REASO-B & $0.923 * *$ & Valid & \\
\hline & & REASO-C & $0.866 * *$ & Valid & \\
\hline & & REASO-D & $0.880 * *$ & Valid & \\
\hline \multirow{4}{*}{3.} & \multirow{4}{*}{ Self-immunity element } & SELF-A & $0.835^{* *}$ & Valid & \multirow{4}{*}{0.820} \\
\hline & & SELF-B & $0.868 * *$ & Valid & \\
\hline & & SELF-C & $0.823 * *$ & Valid & \\
\hline & & SELF-D & $0.856 * *$ & Valid & \\
\hline \multirow{4}{*}{4.} & \multirow{4}{*}{ Knowledge condition } & KNOW-A & $0.827 * *$ & Valid & \multirow{4}{*}{0.849} \\
\hline & & KNOW-B & $0.898 * *$ & Valid & \\
\hline & & KNOW-C & $0.854 * *$ & Valid & \\
\hline & & KNOW-D & $0.882 * *$ & Valid & \\
\hline \multirow{4}{*}{5.} & \multirow{4}{*}{ Morality condition } & MORAL-A & $0.881^{* *}$ & Valid & \multirow{4}{*}{0.830} \\
\hline & & MORAL-B & $0.912 * *$ & Valid & \\
\hline & & MORAL-C & $0.896 * *$ & Valid & \\
\hline & & MORAL-D & $0.818^{* *}$ & Valid & \\
\hline \multirow{5}{*}{6.} & \multirow{5}{*}{ SMEs' performance } & BSC-A & $0.892 * *$ & Valid & \multirow{5}{*}{0.886} \\
\hline & & BSC-B & $0.915^{* *}$ & Valid & \\
\hline & & BSC-C & $0.868 * *$ & Valid & \\
\hline & & BSC-D & 0.909* & Valid & \\
\hline & & BSC-E & $0.854^{* *}$ & Valid & \\
\hline
\end{tabular}

Table 2. Validity and reliability test of variables' used

**Significant at 0.01 level, and * significant at 0.05 level.

Source: own study.

Besides the main model, we conducted a sensitivity analysis using each of the perspectives of the BSC (financial, customer, internal process, learning, and environmental), which effected in the adoption of the following five additional regression equations:

$$
\begin{gathered}
\text { Finance }=\beta 0+\beta 1 \cdot \mathrm{MODER}+\beta 2 \cdot \mathrm{REASO}+\beta 3 \cdot \mathrm{SELF}+\beta 4 \cdot \mathrm{KNOW}+ \\
+\beta 5 \cdot \mathrm{MORAL}+\varepsilon \\
\text { Customer }=\beta 0+\beta 1 \cdot \mathrm{MODER}+\beta 2 \cdot \mathrm{REASO}+\beta 3 \cdot \mathrm{SELF}+\beta 4 \cdot \mathrm{KNOW}+ \\
+\beta 5 \cdot \mathrm{MORAL}+\varepsilon
\end{gathered}
$$

Internal process $=\beta 0+\beta 1 \cdot \mathrm{MODER}+\beta 2 \cdot \mathrm{REASO}+\beta 3 \cdot \mathrm{SELF}+\beta 4 \cdot \mathrm{KNOW}$ $+\beta 5 \cdot \operatorname{MORAL}+\varepsilon$ 


$$
\begin{gathered}
\text { Learning }=\beta 0+\beta 1 \cdot \operatorname{MODER}+\beta 2 \cdot \operatorname{REASO}+\beta 3 \cdot \mathrm{SELF}+\beta 4 \cdot \mathrm{KNOW}+ \\
+\beta 5 \cdot \mathrm{MORAL}+\varepsilon
\end{gathered}
$$

Environmental $=\beta 0+\beta 1 \cdot \mathrm{MODER}+\beta 2 \cdot \mathrm{REASO}+\beta 3 \cdot \mathrm{SELF}+\beta 4 \cdot \mathrm{KNOW}+$

$$
+\beta 5 \cdot \mathrm{MORAL}+\varepsilon
$$

\section{RESULTS AND DISCUSSION}

Among the 600 SMEs that responded to the questionnaire, respondents were 527 males (87.83\%), and 73 females (12.17\%). Samples were collected from 150 firms (25.00\%) from each of the four regions of Thailand (northern, north-eastern, central, and southern). In terms of firm size, there were 547 small firms (91.16\%), while 53 were medium firms (8.84\%). In terms of firm type, most common respondents were ordinary person - such as sole proprietorship, group of persons, or ordinary partnership - in the case of 553 firms $(92.17 \%)$, while 47 firms (7.83\%) were a juristic person, such as limited partnership, company limited, or company listed. Finally, the most common SMEs' age was below 10 years among 585 firms (97.50\%), while 15 SMEs (2.50\%) saw 10 or more years of operation.

When investigating the extent of the SEP practice and the level of performance measured by the BSC - based on the responses to the questionnaire - the study found that all elements and conditions of SEP were implemented at a high level, as shown in Table 3. As we can see in Table 3, the moderation element was the most common aspect of SEP practiced by the sample of SMEs, followed by the morality condition, the reasonableness element, the selfimmunity element, and the knowledge condition. In terms of performance as measured by the BSC, the study found that the averages for each of the BSC perspective were also high.

Table 3. The level of SEP practice and performance measured by the BSC of SMEs in Thailand in 2019

\begin{tabular}{|l|r|r|r|r|r|c|}
\hline \multicolumn{1}{|c|}{ SEP Practice } & Min. & Max. & \multicolumn{1}{c|}{ Mean } & \multicolumn{1}{c|}{ S.D. } & \multicolumn{1}{c|}{ Rank } & Level \\
\hline Moderation element & 2.25 & 5.00 & 3.99 & 0.61 & 1 & High \\
\hline Reasonableness element & 1.50 & 5.00 & 3.77 & 0.71 & 3 & High \\
\hline Self-immunity element & 1.75 & 5.00 & 3.63 & 0.75 & 4 & High \\
\hline Knowledge condition & 1.50 & 5.00 & 3.51 & 0.69 & 5 & High \\
\hline Morality condition & 1.00 & 5.00 & 3.89 & 0.69 & 2 & High \\
\hline SMEs' Performance by BSC & Min. & Max. & Mean & S.D. & Rank & Level \\
\hline Financial perspective & 1.50 & 5.00 & 3.85 & 0.57 & 2 & High \\
\hline Customer perspective & 1.00 & 5.00 & 3.84 & 0.62 & 3 & High \\
\hline Internal Process perspective & 1.00 & 5.00 & 3.71 & 0.59 & 5 & High \\
\hline Learning perspective & 1.00 & 5.00 & 3.78 & 0.66 & 4 & High \\
\hline Environmental perspective & 2.00 & 5.00 & 3.93 & 0.62 & 1 & High \\
\hline Average BSC & 2.20 & 5.00 & 3.82 & 0.51 & - & High \\
\hline
\end{tabular}

Source: own elaboration of the study $(n=600)$.

Before conducting the multiple regression analysis, assumptions that the data was normally distributed and that there was no multicollinearity among the variables included in the analysis were first tested. Table 4 shows the correlation matrix used to test for multicollinearity among the six variables used in this study, consisting of one dependent variable and five independent variables. Based on a fixed effects model for panel testing, the variance inflation factor ) VIF( of the correlation matrix among the var- 
iables was 2.468 , which indicates that there appeared no multicollinearity, which would be indicated by the VIF exceeding 10 (Gunno \& Penawuthikul, 2018, Vanstraelen et al., 2012). Moreover, the low coefficients in the correlation matrix between the variables used in the study indicated that multicollinearity was unlikely to be a problem in multiple regression (Suttipun, 2018). Based on the correlation coefficients among the six variables used in this study, there appeared significant positive correlations among BSC, MODER, REASO, SELF, KNOW, and MORAL at the 0.01 level.

Table 4. The correlation matrix of variables

\begin{tabular}{|l|r|r|r|r|r|c|}
\hline \multicolumn{1}{|c|}{ Variables } & \multicolumn{1}{c|}{ BSC } & MODER & \multicolumn{1}{c|}{ REASO } & \multicolumn{1}{c|}{ SELF } & KNOW & MORAL \\
\hline BSC & 1.000 & \multicolumn{1}{c|}{-} & \multicolumn{1}{c|}{-} & - & \multicolumn{1}{c|}{-} & - \\
\hline MODER & $0.595^{* *}$ & 1.000 & \multicolumn{1}{c|}{-} & - & \multicolumn{1}{c|}{-} & - \\
\hline REASO & $0.613^{* *}$ & $0.671^{* *}$ & 1.000 & - & - & - \\
\hline SELF & $0.578^{* *}$ & $0.566^{* *}$ & $0.661^{* *}$ & 1.000 & - & - \\
\hline KNOW & $0.520^{* *}$ & $0.435^{* *}$ & $0.483^{* *}$ & $0.494^{* *}$ & 1.000 & - \\
\hline MORAL & $0.644^{* *}$ & $0.506^{* *}$ & $0.503^{* *}$ & $0.367^{* *}$ & $0.431^{* *}$ & 1.000 \\
\hline Mean & 3.820 & 3.990 & 3.770 & 3.630 & 3.510 & 3.890 \\
\hline Standard Deviation & 0.510 & 0.610 & 0.710 & 0.750 & 0.690 & 0.690 \\
\hline Variance Inflation Factor & - & 2.055 & 2.468 & 1.985 & 1.495 & 1.512 \\
\hline
\end{tabular}

**Significant at 0.01 level, and * significant at 0.05 level.

Source: owe study base on the research $(n=600)$.

Table 5 indicates the outcome of the multiple regression analysis testing the influence of the five elements and conditions of SEP (denoted as MODER, REASO, SELF, KNOW, and MORAL) on performance measured by the BSC for the sample of SMEs. The study result of model 1 showed that all the elements and conditions of SEP influenced performance as measured by the BSC at the 0.01 level. Therefore, all the hypothesis tested in this study were accepted. On the other model, the study also found the positive influence of each elements and conditions of SEP practice on SMEs' performance. However, by using control variables, even though there was a significant relationship between SIZE, TYPE, and the BSC at 0.05 level, while AGE had no influenced on the BSC at 0.05 level.

This result is consistent with prior studies of Nuttavuthisit (2005), Pruetipibultham (2010), Ekwueme et al. (2013), and Suriyankietkaew and Avery (2016), which all find a positive influence of SEP practice and disclosure on the performance of businesses, while the positive relationship between SEP practice and performance can be explained by stakeholder theory, since by satisfying stakeholder demands, businesses can derive benefits such as improved reputation, higher firm value, competitive advantage, and better performance (Donaldson \& Preston, 1995; Cheng \& Fan, 2010; Parmar et al., 2010). For example, Ekwueme et al. (2013) show that customers tend to purchase products from businesses that care about the welfare of their customers while also contributing to the well-being of society, environment, sustainable development (Jitsuchon, 2019). Moreover, in terms of discussion by using empirical data from the previous related studies, Suriyankietkaew and Avery (2016) reveal that the SEP practice can influence the (sound) decision to increase firm profitability, competitive advantage, and sustainability. Therefore, many businesses in Thailand put SEP into practice to maximise customer loyalty and satisfying customers' demands. This study demonstrates that SEP is not only implemented in Thailand by large firms - as 
discovered by Suttipun and Saefu (2017) and Suttipun (2018), who find positive relationships between SEP practice and disclosure - or corporate performance among companies listed on the Stock Exchange of Thailand, but that many SMEs also implement SEP as their management strategy. This is because the SEP practice can assist company management in making sound decisions, and it can increase corporate performance and lead to sustainable development (Pruetipibultham, 2010; Jitsuchon, 2019).

In model 2 of Table 5 , by using a control variable, this study found that there is a positively significant relationship between firm size and SMEs performance. The result provides that medium-sized enterprises had higher performance measuring by balanced scorecard than small enterprises. The result of negative relationship between firm age and SMEs performance appears to stem from SMEs that operate longer than 10 years and have higher performance than younger firms. However, there was no relationship between firm type and SMEs performance measured by the BSC. This may be because there were only 47 firms that were either limited partnership, company limited, or company listed, while 553 SMEs firms were ordinary persons.

Table 5. Multiple regression models of Thai SMEs in 2019

\begin{tabular}{|c|c|c|c|c|}
\hline \multirow{2}{*}{ Variables } & \multicolumn{2}{|c|}{ Model 1} & \multicolumn{2}{|c|}{ Model 2} \\
\hline & B & t (sig.) & B & t (sig.) \\
\hline -Constant- & 1.049 & $\begin{array}{r}10.787 \\
\left(0.000^{* *}\right)\end{array}$ & 1.160 & $\begin{array}{r}8.424 \\
\left(0.000^{* *}\right)\end{array}$ \\
\hline MODER & 0.123 & $\begin{array}{r}3.997 \\
\left(0.000^{* *}\right) \\
\end{array}$ & 0.118 & $\begin{array}{r}3.814 \\
\left(0.000^{* *}\right) \\
\end{array}$ \\
\hline REASO & 0.089 & $\begin{array}{r}3.037 \\
\left(0.002^{* *}\right) \\
\end{array}$ & 0.093 & $\begin{array}{r}3.189 \\
(0.002 * *) \\
\end{array}$ \\
\hline SELF & 0.145 & $\begin{array}{r}5.829 \\
\left(0.000^{* *}\right) \\
\end{array}$ & 0.145 & $\begin{array}{r}5.801 \\
(0.000 * *) \\
\end{array}$ \\
\hline KNOW & 0.098 & $\begin{array}{r}4.202 \\
(0.000 * *) \\
\end{array}$ & 0.105 & $\begin{array}{r}4.445 \\
\left(0.000^{* *}\right) \\
\end{array}$ \\
\hline MORAL & 0.276 & $\begin{array}{r}11.802 \\
(0.000 * *) \\
\end{array}$ & 0.273 & $\begin{array}{r}11.485 \\
\left(0.000^{* *}\right) \\
\end{array}$ \\
\hline SIZE & - & - & 0.084 & $\begin{array}{r}2.337 \\
\left(0.028^{*}\right) \\
\end{array}$ \\
\hline TYPE & - & - & 0.003 & $\begin{array}{r}0.050 \\
(0.960) \\
\end{array}$ \\
\hline AGE & - & - & -0.182 & $\begin{array}{r}-2.063 \\
(0.040 *)\end{array}$ \\
\hline R Square & & 0.594 & & 0.597 \\
\hline Adjust R Square & & 0.590 & & 0.592 \\
\hline F value (sig.) & & 179.720** & & $113.524 * *$ \\
\hline
\end{tabular}

** Significant at 0.01 level, and * significant at 0.05 level.

Source: own study.

Table 6 shows the results of the sensitivity analysis that refers to the influence of SEP practice on performance, as measured by the BSC for each perspective of performance. The financial and internal process models indicate that MODER, SELF, KNOW, and MORAL had a positive and significant influence on the financial and internal process perspectives 
of performance at the 0.01 level, while there was no relationship between REASO and the financial and internal process perspectives at the 0.05 level. On the other hand, in the customer and learning models, this study found that MODER, REASO, SELF, and MORAL had a positive influence on the customer and learning perspectives of performance at the 0.01 level, while no relationship appeared between KNOW and the customer and learning perspectives at the 0.05 level. Finally, for the learning model, the study found that all elements and conditions of SEP had a positive influence on the learning perspective of performance at either the 0.01 or 0.05 levels.

Table 6. Sensitivity analysis models of SMEs in Thailand in 2019

\begin{tabular}{|c|c|c|c|c|c|c|c|c|c|c|}
\hline \multirow{2}{*}{ Variables } & \multicolumn{2}{|c|}{ Financial } & \multicolumn{2}{|c|}{ Customer } & \multicolumn{2}{|c|}{ Internal } & \multicolumn{2}{|c|}{ Learning } & \multicolumn{2}{|c|}{ Environmental } \\
\hline & B & t (sig.) & B & t (sig.) & B & t (sig.) & B & t (sig.) & B & t (sig.) \\
\hline -Cons- & 1.336 & $10.043 * *$ & 0.853 & $6.311^{* *}$ & 1.295 & $9.104^{* *}$ & 0.657 & $4.481^{* *}$ & 1.106 & $7.982 * *$ \\
\hline MODER & 0.132 & $3.142 * *$ & 0.128 & $2.978 * *$ & 0.101 & $2.240 * *$ & 0.159 & $3.414 * *$ & 0.097 & 2.199* \\
\hline REASO & 0.009 & 0.235 & 0.143 & $3.522 * *$ & 0.027 & 0.629 & 0.138 & $3.143 * *$ & 0.126 & $3.030 * *$ \\
\hline SELF & 0.154 & $4.544 * *$ & 0.172 & $4.974^{* *}$ & 0.119 & $3.277^{* *}$ & 0.130 & $3.487^{* *}$ & 0.148 & $4.193 * *$ \\
\hline KNOW & 0.090 & $2.803 * *$ & 0.038 & 1.168 & 0.247 & $7.230 * *$ & 0.079 & $2.227^{*}$ & 0.038 & 1.142 \\
\hline MORAL & 0.276 & $8.632 * *$ & 0.308 & 9.339** & 0.158 & $4.608 * *$ & 0.313 & $8.882^{* *}$ & 0.330 & $9.903 * *$ \\
\hline R square & & 0.390 & & 0.476 & & 0.349 & & 0.450 & & 0.438 \\
\hline Adj. R & & 0.385 & & 0.472 & & 0.344 & & 0.445 & & 0.433 \\
\hline F value & & $78.763^{* *}$ & & $11.666 * *$ & & $66.004 * *$ & & $00.437^{* *}$ & & $95.854 * *$ \\
\hline
\end{tabular}

**Significant at 0.01 level, and * significant at 0.05 level.

Source: own study.

\section{CONCLUSIONS}

Based on SMEs responses to the questionnaire, the study answers the research questions that both SMEs SEP practice and performance appeared at a high level, as measured by the BSC. Moreover, in regard to the elements and conditions of SEP, the moderation element was the most commonly practiced by the sample of SMEs, followed by the morality condition, the reasonableness condition, self-immunity elements, and the knowledge condition. Furthermore, based on the multiple regression analysis, the study found that all elements and conditions of SEP positively and significantly influence the performance of SMEs, as measured by the BSC. Finally, using control variables, the study found the significant relationship between firm size, firm age, and SMEs' performance.

In terms of its theoretical contribution, the finding of a positive influence of SEP practice on performance, as measured by the BSC, demonstrates that the stakeholder theory can be used to explain the fact that SMEs in Thailand implement SEP to satisfy stakeholder demands. The result also sheds light on how SMEs in an emerging economy use Eastern management strategies and what are their benefits, as measured by the BSC, which primarily is a Western method of performance measurement. Finally, the result of this study should encourage businesses in Thailand and elsewhere to adopt SEP as a practical corporate strategy, in the form created by His Majesty the King of Thailand, Bhumibhol Adulyadej.

In terms of practical contribution and implications, the finding of the positive influence of SEP practice on both financial and non-financial performance, as measured by the BSC, 
should encourage businesses to adopt SEP as a means of contributing to sustainable development. Moreover, business owners and top management can use SEP as a practical management tool on which to operate businesses, instead of adopting Western management models. The finding of the positive influence of SEP practice on performance should also encourage multinational companies and firms in other countries to learn more about Eastern management practices - in this case, the SEP practice - to improve their overall performance by balancing the economic, social, and environmental perspectives.

There are some limitations to this study's findings. Firstly, the use of a mailed questionnaire must be mentioned as a limitation because it included only closed-ended and no open-ended questions. Therefore, the study could not provide an in-depth investigation of the reasons for the SMEs implementation of SEP practice in businesses. Secondly, the sample used was only 600 SMEs in Thailand, which can be viewed as a limitation of this study, because there were only $0.1 \%$ of all SMEs in Thailand that has around 600 000 firms. Next, data collection adopted from listed companies (large firms) in Thailand was limited because the context of SMEs may differ with large enterprises. Finally, even though the SEP concept and its practical application has already spread to other countries, the study focused only on Thailand. Therefore, based on the results of positive relationship of all elements and conditions of SEP practice and SMEs' performance measured by the BSC, in-depth interview to SMEs will be investigate how and why the SMEs would like to have the SEP concept into their operation. In addition, there will be comparative research into the other countries such as Bhutan, Nepal, Laos, and TimorLeste where SEP concept has been used as business management practice. In order to small number of samples and mismatch questionnaire, the future study will develop an appropriate questionnaire to survey more number of Thai SMEs.

\section{REFERENCES}

Avery, G.C. (2005). Leadership for sustainable futures: achieving success in a competitive world. Cheltenham, UK: Edward Elgar.

Carrol, A., \& Bucholtz, A.K. (2006). Business and society: ethics and stakeholder management. New York, USA: Thompson.

Cheng, L.H., \& Fan, H.K. (2010). Drivers of environmental disclosure and stakeholder expectation: evidence from Taiwan. Journal of Business Ethics, 96(3), 435-451.

Collier, P.M. (2008). Stakeholder accountability: a field study of the implementation of a governance improvement plan. Accounting, Auditing \& Accountability Journal, 21(7), 933-953.

Cronbach, L.J. (1951). Coefficient alpha and the internal structure of tests. Psychometric, 16(2), 297-334.

Decharin, P. (2004). Implementing balance scorecard (Edition 4). Bangkok: Chulalongkorn University.

Deegan, C. (2002). Introduction: The legitimizing effect of social and environmental disclosures-a theoretical foundation. Accounting, Auditing and Accountability Journal, 15(3), 282-311.

Donaldson, T., \& Preston, L. (1995). The stakeholder theory of the corporation: concept, evidence, and implications. Academic of Management Review, 20(1), 65-91.

Dutta, S., \& Evrard, P. (1999). Information technology and organization within European small enterprises. European Management Journal, 17(3), 239-251. 
Ekwueme, C.M., Egbunike, C.F., \& Onyali, C.I. (2013). Benefits of triple bottom line disclosures on corporate performance: an exploratory study of corporate stakeholders. Journal of Management and Sustainability, 3(2), 201-230.

Elkington, J. (1997). Cannibals with fork: the Triple Bottom Line of 21st Century business. Capstone, Oxford.

European Commission. (2019). Small and medium-sized enterprises (SMEs). Retrieved from ec.europa.eu on March 15, 2020.

Freeman, R.E. (1984). Strategic management: a stakeholder approach. Boston: Pitman.

Gray, R., Collison, D., \& Bebbington, J. (1998). Environmental and social accounting and reporting. Dundee, UK: University of Dundee.

Garrison, R.H., Noreen, E.W., Brewer, P.C., Cheng, N.S., \& Yuen, K.C. (2015). Managerial Accounting Asia Global. United State: McGraw-Hill Education.

Gunno, P., \& Penawuthikul. P. (2018). Factors affecting disclosure quality on key audit matters in auditor's report in Thailand. Journal of MCU Nakhondhat, 5(3), 926-942.

Hatetong, P. (2016). The relationship between ownership structure, environment, and performance measurement of finance and non-finance (Research Paper in National Conference of Walailak Research No. 4). Retrieved from www.research.wu.ac.th on May 25, 2019.

Jitsuchon, S. (2019). Thailand's sufficiency economy philosophy as an alternative path to sustainable development. European Journal of Sustainable Development, 8(2), 191-200.

Joshi, P.L., \& Gao, S.S. (2009). Multinational corporate social and environmental disclosures (CSED) on web sites. International Journal of Commerce \& Management, 19(1), 27-44.

Kantabutra, S. (2006). Relating vision-based leadership to sustainable business performance: a Thai perspective. Kravis Leadership Institute Leadership Review, 6(1), 37-53.

Kantabutra, S. (2010). Philosophy of suffiency economy in business and sustainable development. Human Resource Management by Sufficiency Economy Philosophy, 17(1), 143-185.

Kaplan, R.S., \& Norton, D.P. (1992). The balanced socrecard-measures that drive performance. Havard Business Review, 70(1), 72-82.

Kaplan, R.S., \& Norton, D.P. (1996). The balanced socrecard: translating strategy into action. MA: Harvard Business Scholl Press.

Kulkalyuenyong, P. (2018). Strategies in building corporate enterpreneurship. Journal of Humanities and Social Sciences Rajapruk University, 4(1), 1-11.

Mongsawad, P. (2010). The philosophy of the sufficiency economy: a contribution to the theory of development. Asia-Pacific Development Journal, 17(1), 123-143.

Mongsawad, P., \& Thongpakde, N. (2016). Sufficiency economy philosophy: a holistic approach to economic development and mainstream economic thought. Asian Social Science, 12(7), 136-142.

Nuttavuthisit, K. (2005). Applying sufficiency economy philosophy in business organizations: a case of Panda Jewelry (unpublished paper). Sufficiency Economy Unit, Office of National Economic and Social Development Board, Thailand.

Noim Uddin, S., Taplin, R., \& Yu, X. (2006). Energy, environment and development in Bhutan. Renewable and Sustainable Energy Reviews, 11(3), 2083-2103.

Norreklit, K. (2000). The balance on the balanced scorecard: a critical analysis of some of its assumptions. Management Accounting Research, 11(1), 65-88.

Office of SMEs Promotion (OSMEP). (2018). SMEs Promotion Scheme Number 4 (2560-2564 B.C.) Retrieved from www.sme.go.th/th/download.php?modulekey=12 on March 10, 2019. 
Organization for Economic Co-operation and Development (OECD). (2017). Enhancing the Contributions of SMEs in a Global and Digitalized Economy. Retrieved from www.oecd.org/mcm/documentsC-MIN-2018-EN.pdf on October 25, 2018.

Parmar, B.L., Freeman, R.E., Harrison, J.S., Wicks, A.C., Purnell, L., \& De Colle, S. (2010). Stakeholder theory: the state of the art. Academy of Management Annals, 4(1), 403-445.

Pruetipibultham, O. (2010). The sufficiency economy philosophy and strategic HRD: a sustainable development for Thailand. Human Resource Development International, 13(1), 99-110.

Revenue Department. (2018). SMEs Characteristics. Retrieved from www.re.go.th on April 16, 2019.

Silpcharu, T. (2010). Research and statistical analysis by SPSS (Edition 11). Bangkok: S.R. Printing Mass Product.

Shone, J.J. (2014, September). The sufficiency economy philosophy and its international role in sustainable development as seem in application in the SEP model villages of Laos and Timor-Leste. Paper presented at the 3rd MSSRC International Conference on Mekong Region and ASEAN in Transition: People and Tranborder. Ubon Ratchathani, Thailand.

Skouloudis, K. (2009). Development of an evaluation methodology for triple bottom line reports using international standards on reporting. Environmental Management, 44(2), 298-311.

Srisa-ard, B. (2010). Introductory Research. Bangkok: Suweeriyasarn.

Suriyankietkaew, S., \& Avery, G. (2016). Sustainable leadership practices driving financial performance: empirical evidence from Thai SMEs. Sustainability, 8(1), 1-14.

Suttipun, M. (2018). The influence of corporate governance, sufficiency economy philosophy reporting on corporate financial performance: evidence from Thailand. Asia-Pacific Journal of Business Administration, 10(1), 79-99.

Suttipun, M. (2019). The longitudinal study of sufficiency economy philosophy reporting of listed companies in the Stock Exchange of Thailand. Asia-Pacific Journal of Business Administration, 11(2), 187-206.

Suttipun, M., \& Saefu, S. (2017). Investigation of sufficiency economy philosophy reporting in Thailand. DLSU Business \& Economics Review, 26(2), 53-65.

Suttipun, M., \& Sittidate, N. (2016). Corporate social responsibility reporting and operation performance of listed companies in the Stock Exchange of Thailand. Songklanakarin Journal of Social Sciences and Humanities, 22(1), 269-295.

Teeratanachaikul, K. (2010). Performance measurement by balance scorecards in software industry. Srinakharinwirot Business Journal, 2(1), 135-147.

ThaiPat Institute. (2017). The KPI's of Sustainable Development Reporting of Listed Company in the Stock Exchange of Thailand. Retrieved from www.thaipat.org on October 3, 2017.

The Ministry of Industry. (2019). Definition of SMEs in Thailand. Retrieved from www.industry.go.th on September 10, 2019.

UNESCO. (2013). Towards a Sufficiency Economy \& New Ethical Paradigm for Development. UNESCO, France.

Vanstraelen, A., Schelleman, C., Meuwissen, R., \& Hofmann, I. (2012). The audit reporting debated seemingly intractable problems and solutions. European Accounting Review, 21(2), 193-215.

Williams, R.I., Manley, S.C., Aaron, J.R., \& Daniel, F. (2018). The relationship between a comprehensive strategic approach and small business performance. Journal of Small Business Strategy, 28(2), 33. 


\section{Appendix: Questionnaire}

The Influence of Sufficiency Economy Philosophy Practice on SMEs' Performance in Thailand

\section{Section 1. General information}
1. Gender
( ) Male
( ) Female
2. Work Position
( ) General Manager
() Specific Manager
() Owner
() other
3. Firm Location
4. Firm Size
() Northern Thailand
( ) North-Eastern Thailand
( ) Central Thailand
( ) Southern Thailand
( ) Small Enterprise (Total assets less than 50 million baht)
() Medium-Sized Enterprise (Total assets equal or more than 50 million baht)
5. Firm Type ordinary partnership)
( ) Juristic Person (i.e. limited partnership, company limited, company listed)
( ) Ordinary Person (i.e. sole proprietorship, group of persons,
6. Firm Age
( ) Less than 10 years
( ) 10 years or more

\section{Section 2.}

Table 1. SMEs' Sufficiency Economy Philosophy practice

\begin{tabular}{|c|c|c|c|c|c|}
\hline \multirow{2}{*}{ The Sufficiency Economy Philosophy practice } & \multicolumn{5}{|c|}{ Level } \\
\hline & 5 & 4 & 3 & 2 & 1 \\
\hline \multicolumn{6}{|l|}{ Moderation Element } \\
\hline \multicolumn{6}{|l|}{ 1. SME produces its product or service to serve the main target } \\
\hline \multicolumn{6}{|l|}{ 2. SME sets an appropriate price of product or service } \\
\hline \multicolumn{6}{|l|}{ 3. SME focus on long-term outcome rather than short-term outcome } \\
\hline \multicolumn{6}{|l|}{ 4. SME has business alliance with its stakeholders } \\
\hline \multicolumn{6}{|l|}{ Reasonableness Element } \\
\hline \multicolumn{6}{|l|}{ 5. SME understands its business and competitive market } \\
\hline \multicolumn{6}{|l|}{ 6. SME sets its business plan including vision, mission, and goal } \\
\hline \multicolumn{6}{|l|}{ 7. SME assesses and compare its competitor's performance } \\
\hline \multicolumn{6}{|l|}{ 8. SME builds innovation or differentiate } \\
\hline \multicolumn{6}{|l|}{ Self-immunity Element } \\
\hline \multicolumn{6}{|l|}{ 9. SME expands international and national markets } \\
\hline \multicolumn{6}{|l|}{ 10. SME assesses the future business risks } \\
\hline \multicolumn{6}{|l|}{ 11. SME has budgeting plan } \\
\hline \multicolumn{6}{|l|}{ 12. SME has the policy for customer retention and development } \\
\hline \multicolumn{6}{|l|}{ Knowledge Condition } \\
\hline \multicolumn{6}{|l|}{ 13. SME has research and development for its product or service } \\
\hline 14. SME develops management information system & & & & & \\
\hline
\end{tabular}




\begin{tabular}{|l|l|l|l|l|l|}
\hline \multicolumn{1}{|c|}{ The Sufficiency Economy Philosophy practice } & \multicolumn{3}{c|}{ Level } \\
\cline { 2 - 5 } & $\mathbf{5}$ & $\mathbf{4}$ & $\mathbf{3}$ & $\mathbf{2}$ & $\mathbf{1}$ \\
\hline 15. SME trains and develop its staff & & & & & \\
\hline 16. SME has an appropriate accounting system & & & & & \\
\hline Morality Condition & & & & & \\
\hline 17. SME's operation is followed by good corporate governance & & & & & \\
\hline 18. SME keeps quality and customer secret well & & & & & \\
\hline 19. SME has social and environmental activity and spending & & & & & \\
\hline 20. SME promotes moral as its organisational culture & & & & & \\
\hline
\end{tabular}
Note: 5 = the highest level, 4 = high level, 3 = moderate level, 2 = low level, and 1 = the lowest level. Source: own study.

Table 2. The SME's performance measured by the balanced scorecard

\begin{tabular}{|c|c|c|c|c|c|}
\hline \multirow{2}{*}{ The SME's Performance } & \multicolumn{5}{|c|}{ Level } \\
\hline & 5 & 4 & 3 & 2 & 1 \\
\hline \multicolumn{6}{|l|}{ Financial Perspective } \\
\hline \multicolumn{6}{|l|}{ 1. SME increases total revenue and operational profit continually } \\
\hline \multicolumn{6}{|l|}{ 2. SME can reduce an appropriate production costs } \\
\hline \multicolumn{6}{|l|}{ 3. SME has reasonable return of investment } \\
\hline \multicolumn{6}{|l|}{ 4. SME has financial performance following by its goal/budget } \\
\hline \multicolumn{6}{|l|}{ Customer Perspective } \\
\hline \multicolumn{6}{|l|}{ 5. SME increases its market share continually } \\
\hline \multicolumn{6}{|l|}{ 6. SME can keep its customer retention well } \\
\hline \multicolumn{6}{|l|}{ 7. SME takes customers' feedback to improve its operation well } \\
\hline \multicolumn{6}{|l|}{ 8. SME surveys its customers' satisfaction continually } \\
\hline \multicolumn{6}{|l|}{ Internal Process Perspective } \\
\hline \multicolumn{6}{|l|}{ 9. SME has product development and new service to serve its target } \\
\hline \multicolumn{6}{|l|}{ 10. SME can reduce operational time including error reduction } \\
\hline \multicolumn{6}{|l|}{$\begin{array}{l}\text { 11. SME has an efficiency internal management information develop- } \\
\text { ment by using information technology }\end{array}$} \\
\hline \multicolumn{6}{|l|}{ 12. SME can evaluate information for decision making on time } \\
\hline \multicolumn{6}{|l|}{ Learning Perspective } \\
\hline \multicolumn{6}{|l|}{ 13. SME has program to develop and increase its human resources } \\
\hline \multicolumn{6}{|l|}{ 14. SME takes its staff feedback to develop its operation } \\
\hline \multicolumn{6}{|l|}{ 15. SME surveys its staff's satisfaction continually } \\
\hline \multicolumn{6}{|l|}{ 16. SME collects problems of human resource management well } \\
\hline \multicolumn{6}{|l|}{ Environmental Perspective } \\
\hline \multicolumn{6}{|l|}{ 17. SME has an activity on environmental development } \\
\hline \multicolumn{6}{|l|}{ 18. SME is a good refuge of community and environment } \\
\hline \multicolumn{6}{|l|}{ 19. SME is a part of better society and environment } \\
\hline 20. SME can reduce any environmental pollution in community & & & & & \\
\hline
\end{tabular}
Note: 5 = the highest level, 4 = high level, 3 = moderate level, 2 = low level, and 1 = the lowest level. Source: own study. 


\title{
Authors
}

The contribution share of authors is equal and amounted to $50 \%$ each of them.

\section{Muttanachai Suttipun}

Bachelor of Business Administration in Accounting (Prince of Songkla University, Thailand); Master of Business Administration in Accounting for Planning and Control (Kasetsart University, Thailand); and Ph.D. in Accounting and Finance (The University of Newcastle, Australia). Accounting lecturer and director of the Master of Accounting Program (M.Acc.) at the Faculty of Management Sciences (Prince of Songkla University, Thailand). In his research, he focuses on voluntary reporting and disclosure, as well as mandatory reporting. He has published over 60 original papers and one textbook.

Correspondence to: Muttanachai Suttipun, Ph.D., Faculty of Management Sciences, Prince of Songkla University (PSU), HatYai City, Songkhla Province, Thailand. e-mail: muttanachai.s@psu.ac.th ORCID (1) http://orcid.org/0000-0003-2388-6388

\begin{abstract}
Afsa Arwae
Bachelor of Science in Statistics (Prince of Songkla University, Thailand); Master of Economics in Business Economics (National Institute of Development Administration, Thailand); and Ph.D. candidate at the Ph.D. Program (Management) at the Faculty of Management Sciences (Prince of Songkla University, Thailand).

Correspondence to: Afsa Arwae, Ph.D. Program (Management), Faculty of Management Sciences, Prince of Songkla University (PSU), HatYai City, Songkhla Province, Thailand. e-mail: is_memee@hotmail.com

ORCID (1) http://orcid.org/0000-0002-1526-8822
\end{abstract}

\section{Copyright and License}

This article is published under the terms of the Creative Commons Attribution - NoDerivs (CC BY-ND 4.0) License http://creativecommons.org/licenses/by-nd/4.0/

Published by the Centre for Strategic and International Entrepreneurship - Krakow, Poland 